\title{
PENERAPAN BIAYA KUALITAS UNTUK MENINGKATKAN EFISIENSI BIAYA PRODUKSI PADA PT. PERTANI (PERSERO) CABANG SULAWESI UTARA
}

\author{
Oleh: \\ Dwi Nugraha Pratiwi Bawon \\ Jullie J. Sondakh \\ Lidia Mawikere \\ Fakultas Ekonomi dan Bisnis, Jurusan Akuntansi \\ Universitas Sam Ratulangi Manado \\ email: sky_angel54@yahoo.com
}

\begin{abstract}
ABSTRAK
Kualitas merupakan salah satu faktor utama yang harus diperhatikan oleh perusahaan untuk dapat bertahan di tengah persaingan. Dengan peningkatan kualitas secara berkesinambungan akan mengurangi biaya kualitas yang terjadi akibat rendahnya kualitas produk, pengerjaan ulang suatu produk karena ketidaksesuaian dengan standar dan lain-lain. Penurunan biaya kualitas akan meningkatkan keuntungan dan mengurangi biaya terutama biaya produksi. Itu karena biaya kualitas merupakan bagian dari biaya produksi . Adapun tujuan dari penelitian ini adalah untuk mengetahui apakah perusahaan telah menerapkan dan melaporkan biaya kualitas dan untuk mengetahui apakah Apakah penerapan biaya kualitas dapat meningkatkan efisiensi biaya produksi pada PT Pertani (Persero) Cabang Sulawesi Utara. Alat analisis data yang digunakan adalah analisis metode deskriptif dengan pendekatan kuantitatif. Hasil Penelitian menunjukan bahwa pada tahun 2011 biaya kualitas unit produksi PT Pertani (Persero) Cabang Sulawesi Utara Rp365,390,718. Dengan melakukan perbaikan, maka biaya kualitas akan turun sebesar Rp 127,657,118. Oleh karena itu apabila perusahaan menerapkan dan melaporkan biaya kualitas maka perusahaan dapat meningkatkan efisiensi biaya produksi.
\end{abstract}

Kata kunci: Biaya kualitas, Biaya Produksi, Efisiensi

\begin{abstract}
Quality is one of the main factors that must be considered by the company to be able to survive in the competition. By Continuous quality improvement, it will reduce the cost of quality that occurs due to low quality product, rework a product for conformance to standards and others. Decrease in quality costs will increase profits and reduce costs, especially the cost of production. This is because the cost of quality is part of the cost of production. The purpose of this study was to determine whether the company has implemented and report quality costs and to find out if Is the application of quality costs can increase the cost efficiency of production at PT Pertani branch north sulawesi. Data analysis tool used is descriptive analysis method of analysis with a quantitative approach. Research shows that in 2011 the cost of quality production unit PT Pertani branch north Sulawesi amounting to $R p$ 365,390,718. By doing repairs, the cost of quality will be decreased by Rp 127,657,118. Therefore, if companies implement and report quality costs companies can improve efficiency of production costs.
\end{abstract}

Keywords: Cost of quality, Production Cost, Efficiency. 


\section{Latar Belakang Masalah}

\section{PENDAHULUAN}

Keberhasilan suatu perusahaan tidak dapat dicapai begitu saja tanpa adanya usaha yang maksimal dari usaha perusahaan yang bersangkutan. Kualitas merupakan salah satu faktor utama yang harus diperhatikan oleh perusahaan agar tetap dapat bertahan di tengah persaingan yang kompetitif. Dengan meningkatkan kualitas secara berkesinambungan diharapkan akan mengurangi biaya karena terjadi pemborosan akibat rendahnya kualitas, pengerjaan ulang suatu produk karena ketidak sesuaian dengan standar dan biaya lain-lain, sehingga akan dapat meningkatkan keuntungan dari penjualan dan mengurangi biaya. Untuk meningkatkan kualitas selalu dibutuhkan biaya, yang disebut dengan biaya kualitas. dengan menganalisis biaya kualitas dapat diketahui berapa besar biaya sebenarnya yang dikeluarkan perusahaan dalam pengendalian kualitasnya dan kegiatan apa saja yang mengefisienkan biaya yang terjadi tanpa menurunkan kualitas produk yang dihasilkan. Dengan melakukan pencegahan terhadap timbulnya produk cacat maka biaya produksi akan menjadi lebih efisien karena perusahaan tidak perlu menurunkan harga jual produknya karena cacat dan tidak perlu mengerjakan ulang produk cacat, sehingga bahan baku dan tenaga kerja yang ada dapat digunakan seefisien mungkin.

PT. Pertani (Persero) cabang Sulut merupakan salah satu perusahaan yang menunjang kebutuhan pangan nasional. Oleh karena itu produksi benih terutama padi yang dihasilkan haruslah berkualitas agar ketersediaan bahan pangan nasional akan tercapai. Produksi PT. Pertani (Persero) sebagian besar merupakan proyek pemerintah yang dianggarkan sehingga biaya produksi tidak boleh melebihi anggaran yang telah di tetapkan. Perusahaan harus meminimalisasi biaya produksi tanpa menurunkan standar kualitas benih yang dihasilkan, sehingga penulis tertarik untuk mengadakan penelitian tentang penerapan biaya kualitas untuk meningkatkan efisiensi biaya produksi.

\section{Perumusan Masalah}

Berdasarkan latar belakang masalah tersebut, maka perumusan masalah dalam penelitian ini adalah:

a. Apakah PT Pertani (Persero) telah menerapkan dan melaporkan biaya kualitas?

b. Apakah penerapan biaya kualitas dapat meningkatkan efisiensi biaya produksi pada PT Pertani (Persero)?

\section{Tujuan Penelitian}

a. Untuk mengetahui apakah PT Pertani (Persero) telah menerapkan dan melaporkan biaya kualitas.

b. Untuk mengetahui apakah Apakah penerapan biaya kualitas dapat meningkatkan efisiensi biaya produksi pada PT Pertani (Persero).

\section{Manfaat Penelitian}

a. Diharapkan dapat digunakan untuk menambah wawasan pengetahuan terapan khususnya dalam bidang biaya kualitas dan juga dapat dimanfaatkan sebagai bahan referensi atau pembanding yang dapat membantu dalam pengembangan penelitian sejenis.

b. Penelitian ini diharapkan dapat memberikan manfaat dalam hal implementasi dan penerapan teori-teori akuntansi manajemen terutama mengenai penerapan biaya kualitas untuk meningkatkan efisiensi biaya produksi.

c. Menjadi masukan berkaitan dengan biaya kualitas yang dapat digunakan dalam menetapkan kebijakankebijakan di masa yang akan datang terhadap biaya produksi perusahaan.

\section{Akuntansi}

\section{TINJAUAN PUSTAKA}

Menurut Firdaus Ahmad dan Wasila Abdullah (2012:17), akuntansi (accounting) merupakan suatu kegiatan atau jasa yang berfungsi menyediakan informasi kuantitatif terutama yang bersifat keuangan mengenai kesatuan-kesatuan ekonomi tertentu kepada pihak-pihak yang berkepentingan, untuk digunakan sebagai bahan pertimbangan dalam pengambilan keputusan-keputusan ekonomi.

Horngren dan Harrison (2007:4) menyatakan bahwa akuntansi adalah sistem informasi yang mengukur aktivitas bisnis, memproses informasi tersebut menjadi laporan, dan mengkomunikasikan hasilnya kepada para pembuat atau pengambil keputusan. 


\section{Akuntansi Biaya}

Menurut Mulyadi (2012:7) “Akuntansi biaya adalah proses pencatatan, penggolongan, peringkasan dan penyajian biaya pembuatan dan penjualan produk atau jasa, dengan cara-cara tertentu serta penafsiran terhadapnya".

Menurut Horngren, et al. (2008:3) "Akuntansi biaya menyediakan informasi yang dibutuhkan untuk akuntansi manajemen dan akuntansi keuangan. Akuntansi biaya mengukur dan melaporkan setiap informasi keuangan dan non keuangan yang terkait dengan biaya perolehan atau pemanfaatan sumber daya dalam suatu organisasi.

\section{Biaya}

Menurut Mulyadi (2012:8) biaya dalam arti luas yaitu sebagai berikut : "Biaya dalam arti luas adalah pengorbanan sumber ekonomi, yang diukur dalam satuan uang, yang telah terjadi atau kemungkinan akan terjadi untuk tujuan tertentu".Menurut Hansen, Mowen (2009:40), mendefinisikan biaya sebagai berikut: "Biaya adalah kas atau nilai ekuivalen kas yang dikorbankan untuk mendapatkan barang atau jasa yang diharapkan memberi manfaat saat ini atau dimasa datang bagi organisasi”.

\section{Biaya Kualitas}

Krismiaji dan Aryani (2011:390) menyatakan bahwa Biaya Kualitas adalah biaya yang terjadi karena kualitas produk yang dihasilkan rendah. Dengan demikian biaya kualitas berhubungan dengan kreasi, identifikasi, reparasi dan pencegahan terjadinya produk yang tidak sempurna.

Horngren, et al. (2008:288) mengidentifikasi biaya kualitas yaitu biaya yang mengacu pada biaya-biaya yang terjadi untuk mencegah atau biaya-biaya yang timbul sebagai hasil dari memproduksi suatu produk yang berkualitas rendah.

\section{Penggolongan Biaya kualitas}

Horngren, et al. (2008:288)menyatakan bahwa komponen biaya kualitas dapat diklasifikasikan ke dalam 4 klasifikasi, yaitu:

a. Biaya pencegahan (Prevention cost)

Biaya pencegahan terjadi untuk menghindari kualitas yang buruk. Biaya pencegahan adalah biaya yang terjadi untuk menghalangi produksi dari produk yang tidak memenuhi spesifikasi. Item biaya pencegahan antara lain biaya rancangan desain, rancangan proses, evaluasi pemasok, pemeliharaan perlengkapan, pencegahan, dan pelatihan kualitas.Jika biaya pencegahan naik diharapkan cost of failure turun. Dengan demikian biaya pencegahan dikeluarkan untuk menurunkan jumlah produk yang tidak memenuhi syarat (nonconforming unit). Contoh biaya pencegahan terdiri dari rekayasa ulang kualitas, pelatihan kualitas, perencanaan kualitas, audit kualitas, pengkajian rancangan, dan quality circles.

b. Biaya penilaian (Appraisal cost)

Biaya penilaian sebagai biaya yang terjadi untuk mendeteksi unit individu mana yang tidak memenuhi spesifikasi. Contohnya biaya inspeksi dan biaya pengujian produk.

c. Biaya kegagalan internal (Internal failure cost)

Biaya kegagalan internal adalah biaya yang terjadi pada suatu produk yang cacat sebelum di kirim ke pelanggan. Contohnya yaitu biaya cacat produksi, pengerjaan kembali, biaya sisa, pemeliharaan dari kerusakan dan kegagalan internal pada rancangan produksi/proses.

d. Biaya kegagalan eksternal (External failure cost)

Biaya kegagalan eksternal yaitu biaya yang dikeluarkan untuk memperbaiki kerusakan kualitas setelah produk atau jasa yang tidak dapat diterima mencapai pelanggan serta kehilangan peluang laba yang disebabkan oleh penyerahan produk atau jasa yang tidak dapat diterima pelanggan. Contoh biaya kegagalan eksternal yaitu biaya penanganan keluhan dan klaim pelanggan, biaya penggantian garansi, biaya perbaikan dan ongkos kirim produk yang dikembalikan, biaya tuntutan lebih jauh dari pelanggan karena menerima produk yang tidak memenuhi standar kualitas.

\section{Manfaat Informasi Biaya Kualitas}

Penggunaan informasi biaya kualitas untuk keputusan-keputusan implementasi program kualitas dan untuk mengevaluasi efektifitas program tersebut, setelah diimplementasikan, hanya merupakan salah satu potensi penggunaan dari sistem biaya kualitas. Penggunaan-penggunaan pentingnya juga diidentifikasi.

a. Penetapan Harga Strategis 
Informasi biaya kualitas dan implementasi program pengendalian kualitas total berguna untuk pengambilan keputusan strategis yang signifikan. Meningkatkan kualitas bukanlah sebuah obat yang mujarab. Pengurangan biaya yang ditawarkan ternyata tidak mampu menutupi penurunan harga sacara sekaligus.

b. Analisis Produk Baru

Pentingnya pengklasifikasian lebih lanjut dari biaya kualitas menurut perilaku. Penting identifikasi dan pelaporan biaya kualitas secara terpisah. Produk baru dirancang untuk mengurangi biaya kualitas dan hanya dengan mengetahui teknik penetapan biaya kualitaslah dapat menemukan kesalahan dalam analisis laba rugi siklus hidup.

\section{Biaya Produksi}

Biaya produksi merupakan biaya yang berkaitan dengan pembuatan barang dan penyedia jasa. Wijaja (2011:38) mendefinisikan biaya produksi sebagai jumlah dari tiga elemen biaya: bahan baku langsung, tenaga kerja langsung dan overhead pabrik. Bahan baku langsung dan tenaga kerja langsung, keduanya disebut biaya utama (prime cost). Tenaga kerja langsung dan overhead pabrik keduanya disebut biaya konversi.

\section{Unsur-unsur Biaya Produksi}

Unsur-unsur biaya menurut Hansen dan Mowen (2009:42), dapat diklasifikasikan dalam tiga jenis yaitu:

a. Biaya Bahan Baku

Bahan baku merupakan dasar yang akan digunakan untuk membentuk bagian yang menyeluruh menjadi produk jadi. Bahan baku yang digunakan untuk memproduksi dapat diperoleh melalui pembelian lokal, impor atau dari pengolahan sendiri. Biaya bahan baku meliputi harga pokok semua bahan yang dapat diidentifikasi dengan pembuatan suatu jenis produk, dengan mudah dapat ditelusuri atau dilihat perwujudannya di dalam produk selesai. Biaya bahan baku memiliki bagian yang signifikan dari total biaya suatu produk.

b. Biaya Tenaga Kerja Langsung

Tenaga kerja merupakan kegiatan fisik yang dilakukan oleh karyawan untuk mengolah suatu produk. Biaya tenaga kerja langsung meliputi biaya-biaya yang berkaitan dengan penghargaan dalam bentuk upah yang diberikan kepada semua tenaga kerja yang secara langsung ikut serta dalam pengerjaan produk yang hasilnya kerjanya dapat ditelusuri secara langsung pada produk dan upah yang diberikan merupakan bagian yang besar dalam memproduksi produk.

c. Biaya Overhead

Pada umumnya dalam suatu perusahaan biaya bahan baku dan biaya tenaga kerja langsung merupakan biaya produksi langsung. Semua biaya selain biaya bahan baku dan biaya tenaga kerja langsung yang berhubungan dengan produksi adalah biaya produksi tidak langsung. Istilah ini sesuai dengan sifat biaya overhead yang tidak dapat atau sulit untuk ditelusuri secara langsung kepada produk atau aktivitas-aktivitas pekerjaan. Biaya tidak langsung ini terkumpul dalam suatu kategori yang disebut biaya overhead pabrik (BOP) dan membutuhkan suatu proses alokasi yang adil untuk tujuan perhitungan harga pokok produksi atau jasa.

\section{Hubungan Biaya Kualitas dengan Efisiensi Biaya Produksi}

Biaya yang dikeluarkan untuk mengerjakan kembali produk yang gagal yang disebabkan karena pengendalian kualitas dari produk yang tidak baik atau yang tidak sesuai dengan spesifikasi standar kualitas yang telah ditetapkan, akan lebih besar dari pada biaya yang dikeluarkan untuk mencegah kegagalan produk tersebut terjadi. Oleh karena itu, jika kegiatan pengendalian kualitas dapat berjalan dengan baik, tanpa menghasilkan produk cacat dalam proses produksi. Maka pengulangan kerja akan berkurang karena menurunnya unit produk cacat. Hansen Mowen (2009:31) mengatakan bahwa: "Dengan menurunnya unit produk cacat maka sedikit tenaga kerja dan bahan yang digunakan untuk menghasilkan output yang sama. Penurunan jumlah unit cacat memperbaiki kualitas, sementara pengurangan jumlah input yang digunakan meningkatkan efisiensi produksi".

Dengan adanya penurunan biaya kualitas maka efisiensi produksi meningkat maupun sebalikya apabila biaya kualitas menurun maka efisiensi produksi menurun.

\section{Penelitian Terdahulu}

Haslim (2011) dalam skripsinya berjudul peranan analisis biaya produksi untuk meningkatkan efisiensi biaya produksi di PT. Nusantara VIII teh ciater. berdasarkan dari hasil penelitian yang dilakukan dengan melakukan pencegahan terhadap timbulnya produk cacat maka biaya produksi akan menjadi lebih efisien karena 
perusahaan tidak perlu menurunkan harga jual produknya karena cacat dan tidak perlu mengerjakan ulang produk cacat, sehingga bahan baku dan tenaga kerja yang ada dapat digunakan seefisien mungkin.

Fentri Sitanggang (2010), dalam skripsinya berjudul "Pengaruh biaya kualitas terhadap tigkat profitabilitas pada PT. Majesty hotel dan apartement " berdasarkan hasil penelitian menunjukkan bahwa Terdapat pengaruh yang signifikan antara biaya kualitas terhadap tingkat profitabilitas perusahaan

\section{Jenis Penelitian}

\section{METODE PENELITIAN}

Jenis Penelitian dalam skripsi ini merupakan Penelitian Deskriptif yaitu penelitian yang berusaha mendeskripsikan dan menginterpretasikan sesuatu, misalnya kondisi atau hubungan yang ada, pendapat yang berkembang, proses yang sedang berlangsung, akibat atau efek yang terjadi, atau tentang kecenderungan yang tengah berlangsung. Menurut Mudrajat Kuncoro (2009:12), penelitian deskriptif meliputi pengumpulan data untuk diuji hipotesis atau menjawab pertanyaan mengenai status terakhir dari subjek penelitian. Tipe yang paling umum dari penelitian deskriptif ini meliputi penilaian sikap atau pendapat terhadap organisasi, ataupun prosedur.

\section{Tempat dan Waktu Penelitian}

Penelitian dilakukan selama bulan April-Mei 2013 bertempat di Unit Produksi Benih PT Pertani (Persero) berada di Kabupaten Bolaang Mongondow yang beralamat di Jl. AKD Km 30 Desa Siniyung, Kec. Dumoga Timur, Kab. Bolaang Mongondow.

\section{Prosedur Penelitian}

1. Mempelajari teori-teori yang berkaitan dengan biaya kualitas dan teori pendukung lainnya dan melakukan survey awal pada perusahaan yang diteliti untuk mengetahui gambaran umum perusahaan.

2. Mengumpulkan data pendukung penelitian yang akan digunakan, yaitu data mengenai profil perusahaan yang berisi visi dan misi, struktur organisasi, berbagai produk yang dihasilkan, biaya produksi yang ada.Membandingkan data hasil penelitian dan data hasil dokumen serta teori.

3. Menghitung biaya dari setiap kegiatan yang berkaitan dengan biaya kualitas dan membandingkan biaya kualitas dengan taksiran perubahan biaya kualitas , serta menganalisis efisiensi biaya produksi. Data yang di olah adalah data biaya produksi tahun 2011.

4. Membuat kesimpulan berdasarkan hasil penelitian.

\section{Jenis Data}

1. Data kualitatif yang digunakan dalam penelitian ini adalah data yang berupa sejarah perusahaan, visi dan misi, struktur organisasi, dan proses pelaksanaan produksi.

2. Data kuantitatif dipakai adalah biaya-biaya produksi perusahaan pada tahun 2011, biaya dalam setiap tindakan yang dilakukan dalam proses produksi, banyaknya jumlah produksi.

\section{Sumber Data}

Dalam hal ini peneliti menggunakan data primer, dimana data yang dikumpulkan berupa gambaran perusahaan visi dan misi, struktur organisasi, dan informasi biaya-biaya dalam memproduksi produk jadi yang siap dijual.

\section{Teknik Pengumpulan Data}

1. Penelitian Lapangan (Field Research)

a. Dokumentasi yaitu teknik yang dilakukan dengan cara mengumpulkan data melalui dokumen-dokumen perusahaan mengenai data yang terkait dalam hal ini yaitu data tentang sejarah dan perkembangan perusahaan, lokasi perusahaan, struktur organisasi, data produksi dan data biaya yang dikeluarkan perusahaan selama satu periode.

b. Wawancara Langsung yaitu teknik pengumpulan data dengan melakukan tanya jawab langsung kepada pihak-pihak yang terkait dengan masalah yang diteliti

2. Penelitian kepustakaan yaitu penelitian yang dilakukan dengan membaca buku-buku literatur dan referensi lainnya, termasuk hasil-hasil penelitian sebelumnya yang berkaitan dengan pokok permasalahan yang diteliti, sehingga diperoleh landasan teori yang dapat mendukung analisis yang dilakukan. 


\section{Metode Analisis}

Dalam penelitian ini menggunakan metode deskriptif analisis dengan pendekatan kuantitatif, yaitu hasil penelitian yang kemudian diolah dan dianalisis untuk diambil kesimpulannya, artinya penelitian yang dilakukan adalah penelitian yang menekankan analisisnya pada data-data numeric (angka), dengan menggunakan metode penelitian ini akan diketahui hubungan yang signifikan antara variabel yang diteliti, sehingga menghasilkan kesimpulan yang akan memperjelas gambaran mengenai objek yang diteliti.

\section{Gambaran Umum}

\section{HASIL PENELITIAN DAN PEMBAHASAN}

PT Pertani (Persero) merupakan BUMN yang memenuhi kebutuhan domestic maupun ekspor, mengintensifkan pertanian dalam rangka membangun ekonomi nasional yang kuat dan kokoh. Untuk Sulawesi Utara Unit Produksi Benih yang dimiliki oleh PT Pertani (Persero) berkapasitas produksi 2.000 ton per tahun,yang dilengkapi dengan Unit Prosesing dan Gudang penyimpanan. Sejak diresmikan tahun 1989, telah banyak memproduksi benih yang dibutuhkan para petani di Sulawesi Utara dan Gorontalo. Wilayah kerja saat ini mencakup Sulawesi Utara, Gorontalo dan Maluku Utara. Tujuan dari PT Pertani (Persero) adalah turut melaksanakan dan menunjang Kebijaksanaan dan Program Pemerintah di bidang Ekonomi dan Pembangunan Nasional pada umumnya, serta Pembangunan di bidang Pertanian pada khususnya dengan menerapkan prinsipprinsip Perseroan Terbatas.

\section{Visi dan Misi}

1. Visi Perusahaan yaitu Perusahaan Agribisnis terpercaya, pendukung ketahanan pangan nasional

2. Misi Perusahaan yaitu:

a. Menghasilkan sarana produksi dan komoditi pertanian serta jasa yang bermutu dan berdaya.

b. Memasarkan sarana produksi dan komoditi pertanian serta jasa dengan pelayanan prima

c. Mendukung peningkatan kesejahteraan petani dan kelestarian lingkungan untuk menghasilkan produksi yang tinggi serta berperan aktif dalam ketahanan pangan nasional

\section{Hasil Penelitian}

Berdasarkan penelitian yang dilakukan perusahaan belum menerapkan dan melaporkan biaya kualitas. Walaupun belum menerapkan dan melaporkan biaya kualitas terdapat kegiatan-kegiatan yang berkaitan dengan biaya kualitas. Jenis-jenis biaya produksi yang dikeluarkan oleh perusahaan yaitu meliputi biaya bahan baku, biaya tenaga kerja, biaya overhead pabrik. Data biaya produksi Unit Prooduksi PT. Pertani (Persero) Cabang Sulut yaitu sebagai berikut.

Tabel 1. Biaya Bahan Baku UPB PT. Pertani tahun 2011

\begin{tabular}{|l|c|}
\hline \multicolumn{1}{|c|}{ Varietas } & Jumlah (Rp) \\
\hline Cigelis & $767,340,000$ \\
\hline Inpari 8 & $514,800,000$ \\
\hline Ciherang & $268,020,000$ \\
\hline Mekongga & $1,496,016,000$ \\
\hline Inpari 13 & $46,800,000$ \\
\hline Way apo buru & $99,108,000$ \\
\hline Jumlah & $3,192,084,000$ \\
\hline
\end{tabular}

Sumber: PT. Pertani cabang sulut

Tabel 2. Biaya Tenaga Kerja Langsung UPB PT. Pertani (Persero) Tahun 2011

\begin{tabular}{|l|l|l|l|l|}
\hline Varietas & $\begin{array}{l}\text { Jemur/ timbang/ } \\
\text { bongkar (Rp) }\end{array}$ & $\begin{array}{l}\text { Blower/ } \\
\text { sortasi/ } \\
\text { stafel (Rp) }\end{array}$ & Packing (Rp) & $\begin{array}{l}\text { Total biaya } \\
\text { TKL (Rp) }\end{array}$ \\
\hline Cigelis & $12,789,000$ & $11,723,250$ & $12,789,000$ & $37,301,250$ \\
\hline Inpari 8 & $10,725,000$ & $9,295,000$ & $10,725,000$ & $30,745,000$ \\
\hline Ciherang & $5,956,000$ & $4,839,250$ & $5,956,000$ & $16,751,250$ \\
\hline Mekongga & $35,322,600$ & $29,089,200$ & $33,244,800$ & $97,656,600$ \\
\hline Inpari 13 & $1,040,000$ & 845,000 & $1,105,000$ & $2,990,000$ \\
\hline Way apo buru & $2,340,050$ & $2,202,400$ & $2,202,400$ & $6,744,850$ \\
\hline Jumlah & $68,172,650$ & $57,994,100$ & $66,022,200$ & $192,188,950$ \\
\hline
\end{tabular}

Sumber: PT. Pertani Cabang Sulut 
Tabel 3. Biaya Overhead Produksi UPB PT. Pertani tahun 2011

\begin{tabular}{|l|c|}
\hline Komponen biaya & Jumlah (Rp) \\
\hline Angkutan & $21,054,250$ \\
\hline Karung CBKB & $43,732,850$ \\
\hline Solar dan Oli & $46,998,500$ \\
\hline Susut bahan baku (rendemen75\%) & $1,143,345,450$ \\
\hline Label & $20,898,850$ \\
\hline Labolatorium & $10,594,050$ \\
\hline Kantong plastik & $130,883,550$ \\
\hline Karung BBDK & $45,376,050$ \\
\hline Bunga bank & $399,010,500$ \\
\hline Pemeliharaan \& Perbaikan & $6,937,250$ \\
\hline Penyusutan mesin & $44,334,500$ \\
\hline Gaji karyawan & $266,007,000$ \\
\hline Total Biaya & $2,179,172,800$ \\
\hline
\end{tabular}

Sumber: PT. Pertani Cabang Sulut

\section{Hasil Pembahasan}

\section{Biaya kualitas}

Berdasarkan hasil penelitian yang telah dilakukan terdapat kegiatan- kegiatan yang berhubungan dengan biaya kualitas. Penggolongan biaya-biaya yang merupakan biaya kualitas pada Unit Produksi Benih PT. Pertani tahun 2011 yaitu sebagai berikut:

1. Biaya Pencegahan (Prevention Costs)

a) Biaya tenaga kerja pemeliharaan dan perbaikan mesin merupakan

b) Biaya pemeliharaan dan perbaikan mesin

2. Biaya Penilaian (Appraisal Costs)

a) Biaya tenaga kerja pengawas/mandor produksi

b) Biaya pengujian labolatorium

c) Biaya pemeriksaan bahan baku dan bahan pembantu

3. Biaya Kegagalan Intern (Internal Failure Costs)

a) Biaya pengerjaan kembali (rework)

b) Biaya pengujian ulang

Berdasarkan penggolongan tersebut laporan biaya kualitas untuk tahun 2011 adalah sebagai berikut.

Tabel 4. Biaya Kualitas UPB PT. Pertani tahun 2011

\begin{tabular}{|l|l|l|}
\hline Jenis Biaya & Jumlah (Rp) & Persentase (\%) \\
\hline Biaya Pencegahan & & \\
\hline Biaya tenaga kerja pemeliharaan dan perbaikan mesin & $36,600,000$ & 10.0 \\
\hline Biaya pemeliharaan dan perbaikan mesin & $6,937,250$ & 1.9 \\
\hline Jumlah biaya pencegahan & $43,537,250$ & 11.9 \\
\hline Biaya Penilaian & & \\
\hline Biaya tenaga kerja pengawas/mandor produksi & $11,430,000$ & 3.1 \\
\hline Biaya pengujian labolatorium & $10,594,050$ & 2.9 \\
\hline Biaya pemeriksaan bahan baku dan bahan pembantu & $19,800,000$ & 5.4 \\
\hline Jumlah biaya penilaian & $41,824,050$ & 11.4 \\
\hline Biaya kegagalan internal & & \\
\hline Biaya pengujian ulang & $1,857,130$ & 0.5 \\
\hline Biaya pengerjaan ulang & $278,172,288$ & 76.1 \\
\hline Jumlah biaya kegagalan internal & $280,029,418$ & 76.6 \\
\hline Jumlah Biaya kualitas & $365,390,718$ & 100.0 \\
\hline
\end{tabular}

Sumber: Data Olahan 
Berdasarkan tabel 4 dapat terlihat bahwa biaya kualitas yang paling tinggi merupakan biaya kegagalan internal yaitu sebesar $\mathrm{Rp} 280,029,418$ atau $76.6 \%$ dari total biaya kualitas yang ada diikuti oleh biaya pencegahan sebesar Rp 43,537,250 atau 11.9\% dan biaya penilaian sebesar Rp 41,824,050 atau 11.4\%. Hasil ini menunjukkan bahwa perusahaan perlu menangani penyebab terjadinya produk cacat/tidak sesuai standar lebih dulu agar produk cacat yang terjadi dapat berkurang sehingga biaya kegagalan intern dapat ditekan.

\section{Taksiran Biaya Kualitas Setelah Dilakukan Perbaikan}

Berdasarkan penelitian yang dilakukan penulis menyarankan agar perusahaan melakukan perbaikan untuk kualitas dengan asumsi bahwa dengan meningkatkan kegiatan dalam bidang pencegahan produk cacat membuat proses produksi lebih efektif. Kegiatan ini meningkatkan biaya pencegahan, namun diharapkan dapat menurunkan biaya kegagalan internal sehingga biaya produksi menjadi lebih efisien.

Taksiran Biaya pencegahan yang ditambahkan untuk mengurangi biaya produksi yaitu:

1. Biaya pengujian awal pengujian awal berupa kadar air calon benih bahan baku diharapkan kadar air calon benih tidak terlalu tinggi sehingga meminimalisasi biaya produksi atau mengurangi biaya pengujian ulang karena tidak sesuai spesifikasi.

2. Biaya evaluasi pyaitu biaya kegiatan evaluasi terhadap pemasok baik bahan baku maupun bahan pembantu diharapkan dapat mengurangi biaya kegagalan karena bahan baku dan bahan pembantu yang tidak sesuai spesifikasi.

Setelah dilakukan Perbaikan diharapkan laporan biaya kualitas di perkirakan sebagai berikut.

Tabel 5. Rincian Taksiran Perubahan Biaya Kualitas Setelah di Lakukan Perbaikan

\begin{tabular}{|l|l|l|}
\hline Jenis Biaya & Jumlah (Rp) & $\begin{array}{l}\text { Persentase } \\
(\%)\end{array}$ \\
\hline Biaya Pencegahan & & \\
\hline Biaya pengujian awal & $5,565,000$ & 2.3 \\
\hline Biaya evaluasi pemasok & $33,700,000$ & 14.2 \\
\hline $\begin{array}{l}\text { Biaya tenaga kerja pemeliharaan dan perbaikan } \\
\text { mesin }\end{array}$ & $36,600,000$ & 15.4 \\
\hline Biaya pemeliharaan dan perbaikan mesin & $6,937,250$ & 2.9 \\
\hline Jumlah biaya pencegahan & $82,802,250$ & 34.8 \\
\hline Biaya Penilaian & & \\
\hline Biaya tenaga kerja pengawas/mandor produksi & $11,430,000$ & 4.8 \\
\hline Biaya pengujian labolatorium bahan & $10,594,050$ & 4.5 \\
\hline $\begin{array}{l}\text { Biaya pemeriksaan bahan baku dan } \\
\text { pembantu }\end{array}$ & $19,800,000$ & 8.3 \\
\hline Jumlah biaya penilaian & $41,824,050$ & 17.6 \\
\hline Biaya kegagalan internal & & \\
\hline Biaya pengujian ulang & 567,000 & 0.2 \\
\hline Biaya pengerjaan ulang & $112,540,300$ & 47.3 \\
\hline Jumlah biaya kegagalan internal & $113,107,300$ & 47.6 \\
\hline Jumlah Biaya kualitas & $237,733,600$ & 100.0 \\
\hline
\end{tabular}

Sumber: Data Olahan

\section{Efisiensi biaya kualitas terhadap biaya produksi}

Biaya kualitas merupakan bagian dari biaya produksi. Sehingga penurunan maupun kenaikan biaya kualitas akan berakibat pada penurunan ataupun kenaikan biaya produksi. Dengan adanya perbaikan dengan menambahkan biaya penegahan penurunan dan kenaikan biaya kualitas dapat dilihat pada tabel dibawah ini.

Tabel 6. Penurunan dan Kenaikan Biaya Produksi

\begin{tabular}{|l|l|l|l|}
\hline Jenis Biaya & $\mathbf{2 0 1 1}(\mathbf{R p})$ & Taksiran $(\mathbf{R p})$ & Penurunan (-)/ kenaikan(+) biaya \\
\hline Biaya pencegahan & $43,537,250$ & $82,802,250$ & $(+) 39,265,000$ \\
\hline Biaya penilaian & $41,824,050$ & $41,824,050$ & - \\
\hline Biaya kegagalan internal & $280,029,418$ & $113,107,300$ & $(-) 166,922,118$ \\
\hline Jumlah Biaya kualitas & $\mathbf{3 6 5 , 3 9 0 , 7 1 8}$ & $\mathbf{2 3 7 , 7 3 3 , 6 0 0}$ & $\mathbf{( - )} \mathbf{1 2 7 , 6 5 7 , 1 1 8}$ \\
\hline Biaya produksi & $\mathbf{5 , 5 6 3 , 4 4 5 , 7 5 0}$ & $\mathbf{5 , 4 3 5 , 7 8 8 , 6 3 3}$ & $\mathbf{( - ) 1 2 7 , 6 5 7 , 1 1 8}$ \\
\hline
\end{tabular}

Sumber: Data Olahan 
Berdasarkan tabel 6 biaya kualitas mengalami penurunan sebesar Rp 127,657,118. Penurunan biaya ini merupakan bagian dari biaya produksi. Jadi, biaya kualitas dapat membuat biaya produksi lebih efisien sebesar Rp 127,657,118. Table diatas dapat di ringkaskan sebagai berikut.

Tabel 7. Efisiensi Biaya Produksi

Sumber: Data Olahan

\begin{tabular}{|l|l|l|l|l|}
\hline Jenis Biaya & $\begin{array}{l}\mathbf{2 0 1 1} \\
(\mathbf{R p})\end{array}$ & $\begin{array}{l}\text { Taksiran } \\
(\mathbf{R p})\end{array}$ & $\begin{array}{l}\text { Efisiensi } \\
(\mathbf{R p})\end{array}$ & $\begin{array}{l}\text { Persentase } \\
(\boldsymbol{\%})\end{array}$ \\
\hline Biaya kualitas & $365,390,718$ & $237,733,600$ & $127,657,118$ & 34.9 \\
\hline Biaya produksi & $5,563,445,750$ & $5,435,788,633$ & $127,657,118$ & 2.29 \\
\hline Presentase (\%) & 6.57 & 4.37 & & \\
\hline
\end{tabular}

\section{PENUTUP}

\section{Kesimpulan}

Berdasarkan hasil penelitian dan pembahasan, maka dapat disimpulkan bahwa :

1. UPB PT. Pertani cabang Sulawesi utara belum menerapkan biaya kualitas, tetapi biaya kualitas termasuk dalam biaya produksi perusahaan. Pada periode penelitian tahun 2011, biaya kualitas di UPB PT. Pertani yang proporsinya terbesar adalah biaya kegagalan internal diikuti oleh biaya pencegahan dan biaya penilaian. Hal ini menunjukkan bahwa perusahaan lebih menekankan pada kegiatan yang mencegah sampainya produk cacat ke tangan konsumen dibandingkan dengan mencegah terjadinya produk cacat itu sendiri. Kegiatan mencegah sampainya produk cacat ke tangan konsumen akan mengakibatkan kurang efisiennya biaya produksi, sedangkan kegiatan mencegah terjadinya produk cacat itu akan membuat biaya produksi menjadi lebih efisien.

2. Dengan melakukan pencegahan terhadap timbulnya produk cacat dengan melakukan pengujian awal dan evaluasi pemasok, maka diharapkan biaya kegagalan internal dapat ditekan. Hal ini membuat Biaya Produksi menjadi lebih efisien karena perusahaan tidak perlu menurunkan harga jual produknya karena cacat dan tidak perlu mengerjakan ulang produk cacat, sehingga bahan baku dan tenaga kerja yang ada dapat digunakan seefisien mungkin.

\section{Saran}

Penerapan biaya kualitas sebaiknya dilakukan secara teratur dan periodik oleh Perusahaan agar perkembangan yang terjadi pada biaya kualitas dapat segera diketahui dan dievaluasi. Hal ini perlu dilakukan agar perusahaan dapat mengambil tindakan yang akan menurunkan biaya kegagalan internal yang terlalu besar dengan menambah biaya pencegahan yang diperlukan tanpa mengurangi kualitas produk yang dihasilkan. Diharapkan penurunan biaya yang akan terjadi lebih besar dari kenaikan biaya.

\section{DAFTAR PUSTAKA}

Dunia, Firdaus Ahmad dan Wasilah Abdullah, 2012, Akuntansi Biaya Edisi Ketiga, Jakarta, Salemba Empat.

Hansen, Don R. dan Maryanne M. Mowen, 2009, Akuntansi Manjerial Terjemahan Deny Arnos Edisi Kedelapan Jilid 1, Jakarta, Salemba Empat.

Hansen, Don R. dan Maryanne M. Mowen, 2009, Akuntansi Manjerial Terjemahan Deny Arnos Edisi kedelapan Jilid 2, Jakarta, Salemba Empat.

Horngren, Charles.T., Harisson, Wolter.T. 2007. Akuntansi Jilid Satu, Edisi tujuh Penerbit Salemba Empat. Jakarta.

Horngren, Charles T., Srikant M. Datar dan George Foster. 2008, Akuntansi Biaya Terjemahan Desi Adhariani Edisi Kesebelas Jilid 2, Penerbit Erlangga, Jakarta.

Haslim Simora, 2011, Skripsi Peranan Analisis Biaya Produksi Untuk Meningkatkan Efisiensi Biaya Produksi, Universitas Kristen Maranatha. Bandung.

Krismiaji dan Y Anni. Aryani, 2011, Akuntansi Manajemen Edisi Kedua, Penerbit UPP STIE YKPN, Yogyakarta. 
Kuncoro, Mudrajat, 2009, Metode Riset Penelitian Bisnis dan Ekonomi Edisi Ketiga, Penerbit Erlangga, Jakarta. Mulyadi, 2012, Akuntansi Biaya Edisi Kelima, Penerbit UPP STIE YKPN, Yogyakarta.

Sitanggang, Fentri, 2010, Skripsi Pengaruh biaya kualitas terhadap tigkat profitabilitas pada PT. Majesty hotel dan apartement, Universitas Kristen Maranatha, bandung.

Tunggal, Amin Wijaja, 2012, Akuntansi Biaya dan Manajemen, Penerbit Harvarindo, Jakarta.

Witjaksono, Armanto. 2013. Akuntansi Biaya. Yogyakarta : Graha Ilmu. 